\title{
The Literary Expression of Persian Sufism
}

\author{
By BO UTAS
}

It is in itself impossible to separate Persian mysticism from Islamic mysticism in general. When talking about the literary expression of Persian Sufism I intend to restrict myself to works written in New Persian language, i.e. a limitation based on literary and not religious criteria. This is easily comprehensible considering the fact that one and the same Sufi shaykh or poet often wrote both in Persian and Arabic - or in some other of the languages of the Islamic cultural community, as e.g. Turkish or Urdu. With this in mind I shall try to sketch the origin and development of four literary forms within the boundaries of classical Persian literature (c. 900-I600 A.D.).

As is well known, the origins and rise of Sufism have been the object of assiduous discussions during the last hundred years, let us say from the time when Alfred von Kremer published his epoch-making Geschichte der herrschenden Ideen des Islams (Leipzig I868). After Ignaz Goldziher ${ }^{1}$ scholars have generally agreed to see the primary origin of Sufism in an ascetic movement innate in early Islam, and later research, especially the persistent and successful work of Louis Massignon on the roth century mystic al-Hallajj, ${ }^{2}$ has strengthened the conception of the ensuing development of Sufism as fundamentally an organic process within Islam. On the other hand it is obvious that Islamic mysticism in the complicated dynamic system of Near and Middle Eastern religious and philosophical ideas has been subject to manifold influences at every stage of its development. Different Western scholars have stressed these external influences differently; thus Neoplatonic elements have been emphasised by Reynold Nicholson ${ }^{3}$ and many others and Gnostic elements by Hans Heinrich Schaeder. ${ }^{4}$ On the interaction between Muslim and Christian mysticism Asín y Palacios has been a

${ }^{1}$ E.g. Vorlesungen ïber den Islam, Heidelberg I910, pp. 139-200.

${ }^{2}$ E.g. La passion d'al-Halläj, Paris 1922.

${ }^{3}$ E.g. Studies in Islamic Mysticism, Cambridge I 92.

${ }^{4}$ E.g. "Die islamische Lehre vom Vollkommenen Menschen, ihre Herkunft und ihre dichterische Gestaltung", ZDMG, 79, 1925, pp. 192-268. 
prolific writer, ${ }^{1}$ but many others have also contributed on this subject. ${ }^{2}$ Indian influences, which are unambiguously apparent only at a later stage, have been advocated particularly by German scholars as e.g. Richard Hartmann and Max Horten. ${ }^{3}$

The early, ascetic Sufism had its center in Mesopotamia, and there especially in Basra, where we find dominating figures like the austere ascetic alHasan al-Bașri (d. I IO A.H./728 A.D.) and the God-inspired poetess Rābiea al-'Adawiya (d. I85/8or). From Mesopotamia the mystic ideas spread surprisingly fast eastwards to Iran, where they obtained their first foothold in the eastern province of Khorasan, at that time a center of political and religious unrest. The legendary wandering preacher Ibrahim ibn Adham is said to have founded a school of mystics there already in the middle of the eighth century. Under the guidance of his pupil Shaqiq Balkhī (d. 194/8ro) this Khorasanian school flourished in Balkh and soon had offshoots in other important towns of the province, like Nishapur. The first adherents in Khorasan were obviously won among the Arab military colonists, but already from the first half of the ninth century we know of prominent Sufis of Persian descent, e.g. Hātim al-Așamm (d. 237/852), a pupil of Shaqị Balkhī. ${ }^{4}$-Such was the beginning of a development that gave Islamic mysticism an extraordinary position of influence on Persian life and culture, until, about 700 years later, the Safavid shahs persecuted and all but crushed the at that time very extensive Sufi orders. It is significant that this decline of Sufism in Persia coincides with a literary stagnation which generally is considered the termination of the classical period of Persian literature.

The written word and, even more, the oral tradition was from the very beginning of central importance in Sufism. The Koran and the Hadith (traditions of Muhammad) not only constituted the theoretical foundation but also supplied material for preaching and meditation. To them must be added a rapidly growing number of Sufi pseudo-traditions, Koran commen-

1 E.g. El islam cristianizado, Madrid I93 I.

${ }^{2}$ E.g. Tor Andræ, "Zuhd und Mönchtum. Zur Frage von den Beziehungen zwischen Christentum und Islam", Le Monde Oriental, 25, I93 I, pp. 296-327.

${ }^{3}$ For a survey of the history of Western studies on Sufism, see A. J. Arberry, $A n$ Introduction to the History of Șüfism, London ... r942.

${ }^{4}$ See E. Berthels, Islamica, 3, 1927, p. 1, and refs. there. 
taries, legends, parables and anecdotes ${ }^{1}$ as well as, before long, theoretical tracts (risälāt, orig. 'epistles') and poetry. The first century after the death of the Prophet, Arabic was the uncontested religious language, but as early as the first half of the ninth century it must have been necessary for the Sufi preachers in Khorasan to use a language which was understandable also to artisans and bazaar merchants. The New Persian language became a legitimate means of oral exposition and was without doubt presently accepted as a written language.

Unfortunately we can only guess what these first literary specimens looked like, as the oldest preserved Sufi writings in New Persian originate from the eleventh century. But then we encounter fully developed literary forms and a settled terminology, both of which point to a considerable previous development of the literary expressions. Formally this Sufi literature could be divided into prose (nathr), didactic poems (mathnavi, plur. mathnavīyät, prop. 'couplets'), quatrains ( $r u b \bar{a} \bar{a}^{\mathrm{\imath}}$, plur. $r u b \bar{a}^{\mathrm{\imath}} \bar{\imath} y \bar{a} t$, compared to the epigram), and lyrical poems (ghazal, plur. ghazatīyät, compared to the sonnet), as well as a few other poetical forms of less importance. The origin, function and structural development of these forms as such have unfortunately not been the object of much profound study. One of the few who have devoted themselves to more consistent investigations of these problems is the recently deceased Russian orientalist Jevgenij Eduardovič Bertel's (E. Berthels). The following report is to a large extent founded on his works. ${ }^{2}$

The early Sufi prose works in New Persian do not differ much in form and content from their Arabic models. One of the oldest preserved is the treatise Kashf ul-mahjüb ("The revelation of the mystery") of al-Hujvīin (d. 465/ I072-3), ${ }^{3}$ which in its disposition of the material is a direct counterpart to

1 Surprisingly many deal with Christian ascetics, ruhbān (sing. rāhib), cf. T. Andræ, I myrtenträdgården, studier $i$ sufisk mystik, Stockholm 1947 , pp. 20 ff. German transl. Islamische Mystiker, Stuttgart 1960, pp. I $5 \mathrm{ff}$.

2 See esp. "Grundlinien der Entwicklungsgeschichte des Șūfischen Lehrgedichts in Persien", Islamica, 3, I927, pp. I-31; "Osnovnye momenty v razvitii sufijskoj poézii", Vostočnye Zapiski, I, I927, pp. 91-103; these two articles were recently republished, the first-mentioned in Russian translation, in: Bertel's, Izbrannye trudy, [tom 3]: Sufizm i sufijskaja literatura, Moscow 1965, pp. 63-83, 55-62, together with his other works on Sufism, notably the previously unpublished article "Proisxoždenie sufizma i zaroždenie sufijskoj literatury", pp. I3-54.

3 'Translation by R. A. Nicholson, Gibb Memorial Series, 17, London I9I I, repr. r 967 . 
celebrated Arabic works like the Kitäb al-luma of Abū Nașr as-Sarrāj (d. 378/988) and al-Qushairī's Risāla from 437/1045. It gives a broad and moderate exposition of the Sufi doctrines and sects, illustrated by parables and anecdotes from the common Islamic stock and short lives of earlier and contemporary Sufi saints and shaykhs. The text is sparingly interspersed with verses which are always in Arabic. The treatise ends somewhat abruptly with the following opinion on the controversial question of $s a m \bar{a}^{2}$, 'audition', i.e. of music (including singing and, at times, ritual dancing):

I, 'Alī b. 'Uthmān al-Jullābi [al-Hujvīrī], think it more desirable that beginners should not be allowed to attend musical concerts $(\operatorname{sam} \bar{a} h \bar{a})$, lest their natures become depraved. These concerts are extremely dangerous and corrupting, because women on the roofs or elsewhere look at the dervishes who are engaged in audition; and in consequence of this the auditors have great obstacles to encounter. Or it may happen that a young reprobate is one of the party, since some ignorant Şuff is have made a religion (madhhab) of all this and have flung truth to the winds. I ask pardon of God for my sins of this kind in the past, and I implore His help, that He may preserve me both outwardly and inwardly from contamination, and I enjoin the readers of this book to hold it in due regard and to pray that the author may believe to the end and be vouchsafed the vision of God (in Paradise). ${ }^{1}$

Many Persian works were nothing but translations or adaptions of Arabic originals. An early example of this is the enlarged version of as-Sulami's (d. 412/102I) biographical work Ṭabaqāt aș-șüfĩya ("The classes of the Sufis") composed by the learned mystic of Herat 'Abdu'llāh Anșārī (d. 48I/Io89). ${ }^{2}$ These vitae, which are also of great linguistic importance, ${ }^{3}$ became the model for a long series of similar works, so-called tadhkirät (prop. 'memories'). 400 years later (in 1476) they provided the basis for the celebrated biography Nafahāt ul-uns ("Breaths of fellowship") of Anșāri's townsman, the poet and religious teacher Jāmī (d. 898/1492). During these 400 years, however, the stylistic ideals had changed profoundly. Ornate and rhetorically metaphoric ways of expression had become predominant.

Another kind of interaction between Sufi prose in Arabic and Persian is represented by the numerous bilingual writers, of whom one of the most

\footnotetext{
1 Transl. by Nicholson, pp. 419-420.

2 Recently published by 'Abdu'l-Hayy Habibi, Kabul I34I/1962.

${ }^{3} \mathrm{Cf}$. W. Ivanow, "Tabaqat of Ansari in the old language of Herat", $\mathscr{F} R A S$, 1923, pp. I-34, 337-382; also the ed. of Habibi, pp. 27-29.
}

I4-694455 Hartman 
eminent is the theologian Abū Hāmid Muhammad al-Ghazālī (d. 505/I I I I). He wrote his great fundamental work Ihy $\bar{a}^{\text {' }}$ ulüm ad-dinn ("The revivification of the religious sciences") in Arabic but also composed a simplified abridgement of it in Persian under the title Kimiyāy-i sa'ädat ("The alchemy of happiness"), ${ }^{1}$ good evidence of the fact that Arabic was and remained the language of all serious science - even for a Persian. Of greater formal interest is, however, a small Persian work composed by a brother of Abü Haamid, the shaykh Ahmad Ghazāli (d. 520/1 I26). It is called Savānih (i.e. 'Occurrences' or 'Caprices') or "Aphorismen über die Liebe", as it is designated by its editor Hellmut Ritter. ${ }^{2}$ It discusses the true nature of love, but love in itself independent of the object, with "commitment neither to Creator nor creature" (p. 3, line 2o), in short aphoristic statements illustrated by poetic quotations in Arabic and, more often, Persian. The following extract may give an idea of the clear style and often obscure meaning of these aphorisms:

Its [i.e. Love's] perfection is a reproach, and the reproach has three faces: one face towards people and one face towards the Lover and one face towards the Beloved. The face which it has towards people is a sharp sword of jealousy of the Beloved, lest he should look at others, and the face which it has towards the Lover is a sharp sword of jealousy of time, lest he should care for himself, and the face which it has towards the Beloved is a sharp sword of jealousy of love, so that it should receive nourishment even from love and not become tied to desire and that it should not seek anything from without. ${ }^{3}$

This difficult genre did not find much following, but it is worthy of notice that such a great poet as Fakhr ud-din 'Irāqi (d. 688/1289) composed his mystical treatise Lama"āt ("Effulgences") expressively "in the manner of the Savannih"."

Before passing on to the forms of poetry, we should take notice of an interesting stylistic feature, considered a form of prose but in reality an intermediary between prose and poetry, i.e. saj' (orig. 'cooing of doves') or "cadenced and rhymed prose". This device was adopted into Persian from

1 Ed. Ahmmad Ārām, 2 vols., 2nd ed., Tehran 1333.

${ }^{2}$ Bibliotheca Islamica, I 5, Leipzig-Istanbul 1942.

${ }^{3}$ Part 4: I; Ritter's ed. p. I2.

${ }^{4}$ Lama' ät, Foreword; see Kullīyātt-i Shaikh Fakhr ud-dīn ... 'Irāqū, ed. S. Nafīsī, 3 rd ed., Tehran 1338 , p. 376 . 
Arabic, where it was in use already in pre-Islamic times. It is particularly powerful in recitation (e.g. of the Koran) and thus came to be favoured by preachers. Some of the earliest examples of $s a j^{c}$ in New Persian are to be found in the preaching sections of the Sufi treatises of the above-mentioned Anșārī of Herat, e.g. the so-called "Pseudo-Manāzil as-sä'irīn", and in his famous Munāja $\bar{a}$, a kind of fervent and partly versified prayer. ${ }^{1}$

The oldest type of Sufi didactic poem (mathnavi), as we find it in the extensive Hadīqat ul-ḩaqũqah ("Garden of truth") of Hakìm Sanā'ì of Ghazna (d. c. $525 / \mathrm{r}$ 13 $\mathrm{I}^{2},{ }^{2}$ closely resembles in its contents what has been considered recorded preachings, e.g. in the just mentioned works of Anșārī. It consists of a rather incoherent series of moral exhortations and expositions of central Sufi conceptions and terms, exemplified by the common parables. However, a didactic poem of this type hardly replaced the preaching $\left(v a^{\circ} z\right)$ of the shaykh at the Sufi majlis ('session'). It was rather a composition using the material of a number of preachings in prose and rhymed prose with interspersed verses of poetry, intended for the written and oral propaganda.

Berthels seems to maintain ${ }^{3}$ that the mathnavi-form employed by Sanā'i in his didactic poems also formally should be regarded as a development of the musajja'ät ('works in rhymed prose') of Anșāī and others. This supposition is hardly necessary, considering the fact that the mathnavi-form, which simply consists of hemistichs rhymed in pairs, was fully developed already in the first half of the I Ith century as a vehicle of the heroic epic, ${ }^{4}$ as well as of the romantic epic ${ }^{5}$ and even of a kind of ethical didactic poem. ${ }^{6}$ Consequently, Sanā'i had at his disposal both a ready form and a traditionally wellknown content. He composed his mathnaviyät in a new metre, ${ }^{7}$ but the im-

${ }^{1}$ Cf. Berthels, Grundlinien, pp. $9 \mathrm{ff}$.

${ }^{2}$ Ed. M. Radavi, Tehran I329; see also: The First Book of the Hadiqatu'l Haqiqat, or the Enclosed Garden of the Truth ... ed. and transl. by $\mathcal{F}$. Stephenson (Bibliotheca Indica, 21 I), Calcutta I91 I.

${ }^{3}$ Grundlinien, pp. $15 \mathrm{ff}$.

${ }^{4}$ In the measure mutaqärib, seemingly an originally Iranian and syllabic metre adapted to the quantitative Arabic metric system, 'ar $\bar{u} d$, prevalent also in classical Persian poetry.

${ }^{5}$ E.g. Varqah $u$ Gulshäh (from the beginning of the IIth cent.) in the metre mutaqärib and Vīs $u$ Rāmin (from about 1048) in the somewhat heavier metre hazaj.

${ }^{6}$ Composed by the versatile Shi'a-propagandist Nāṣir-i Khusrau in the middle of the is th cent., also in the metre hazaj.

${ }^{7}$ Khafif, which is a little simpler and more vivid than hazaj. 
portant innovation was that he, or some now forgotten precursor, combined this form with Sufi matter. Furthermore, Sanā'i gives us the first example of a Sufi didactic poem of coherent composition, i.e. his Sair ul- $i b \bar{a} d i l \bar{a}^{\prime} l-m a^{\circ} \bar{a} d$ ("Pilgrimage of God's servants to the Hereafter"), ${ }^{1}$ which in its descriptions of the wanderings of the searching human soul has been compared to the Divina Commedia of Dante. ${ }^{2}$

With these two types of didactic poem as a starting-point Berthels sketches two lines of development, one over the grandiose and seemingly unsurveyable Mathnavī-yi månavi ("The mathnavi of spiritual truth") of Jalāl ud-dīn Rūmī (d. 672/1273) and one over Farīd ud-dīn 'Atțāā's (d. c. 6r7/1220) rigorously constructed mathnavīy $\bar{a} t^{4}$ to late classics like Salāmān $u A b s \bar{a} l$ and Yūsuf $u$ Zulaikhã of the already mentioned polyhistor Jāmi, ${ }^{5}$ where the original parable has grown to an independent allegorical romance. There is, however, much to complicate this picture. The genre has been exceedingly popular and much important material lies hidden in manuscript collections of Oriental and other libraries. In many cases it is difficult to establish author or even time of origin. Thus, e.g., a number of mathnavi-poems have been ascribed to Sanā'î, the authors of which most probably belong to later centuries. ${ }^{6}$

Of the Sufi didactic poets 'Atțār and Jalāl ud-dīn Rūmī have attracted by far the greatest attention in the West. Thus Hellmut Ritter in his extraordinarily rich monograph Das Meer der Seele; Mensch, Welt und Gott in den Geschichten des Farīduddīn 'Ațțār (Leiden 1955) investigates the central themes in 'Atțār's four religious mathnavī-poems: Asrārnāmah ("Book of secrets"), Ilāhināmah ("Divine book"), Manțiq ut-tair ("Language of the birds") and Mușibatnämah ("Book of affliction"), and Reynold Nicholson has presented us with Jalāl ud-dīn Rūmì's mighty Mathnavī, which un-

\footnotetext{
1 Ed. H. Kühī-Kirmänī \& S. Nafīsī, Tehran 1316.

${ }^{2}$ Berthels, Grundlinien, p. r9; R. A. Nicholson, A Persian Forerunner of Dante, Towyn-on-Sea 1944, also in the Transactions of the Bombay Branch of the Royal Asiatic Society, 1943.

${ }^{3}$ Grundlinien, pp. $25 \mathrm{ff}$.

${ }^{4}$ Grundlinien, pp. $20 \mathrm{ff}$.

${ }^{5}$ Grundlinien, pp. 29 f.

${ }^{6}$ Such as Bahrām u Bihrüz, Gharīb-nāmah and Tarīq ut-tahqqīq; cf. A. Ateş, "Senâ'̂̀", İslâm Ansiklopedisi, ıо6. cüz, 1965, p. 483 .
} 
doubtedly is one of the supreme achievements in Persian literature, in an extensive work containing text edition, translation and commentaries. ${ }^{1}$

In his Mathnavi Jalāl ud-dīn, like 'Atțār in Mușībatnämah, employs the measure ramal, which is generally somewhat looked down upon because of its simplicity, but it proves very convenient for Jalāl ud-dīn's fluent and exceptionally melodious diction. The following attempts to translate into precise prose or render into congenial verse the famous opening lines of this the Mathnavi par excellence are perhaps more illustrative to the difficulties envolved in such undertakings than to the qualities of the poem:

\section{The lament of the reed-flute is a symbol of the soul's}

\section{sorrow at being parted from the Divine Beloved}

Listen to this reed, how it makes complaint, telling a tale of separation: 'Ever since I was cut off from my reed-bed, men and women all have lamented my bewailing. I want a breast torn asunder by severance, that I may fully declare the agony of yearning. Every one who is sundered far from his origin longs to recapture the time when he was united with it. In every company I have poured forth my lament, I have consorted alike with the miserable and the happy: each became my friend out of his own surmise, none sought to discover the secrets in my heart. My secret indeed is not remote from my lament, but eye and ear lack the light to perceive it. Body is not veiled from soul, nor soul from body, yet to no man is leave given to. see the soul.'

This cry of the reed is fire, it is not wind; whoever possesses not this fire, let him be naught! It is the fire of love that has set the reed aflame; it is the surge of love that bubbles in the wine. The reed is the true companion of everyone parted from a friend: its melodies have rent the veils shrouding our hearts. (Translation A. J. Arberry ${ }^{2}$ )

\section{Einleitung zum Methnewi}

Hör auf der Flöte Rohr, was es verkündet, Hör, wie es klagt, von Sehnsuchtsschmerz entzündet:

Als man mich abschnitt am beschilften See,

Da weinte alle Welt bei meinem Weh,

Ich such ein sehnend Herz, in dessen Wunde

Ich giesse meines Trennungs-Leides Kunde;

${ }^{1}$ The Mathnawi of Falálu'ddín Rúmi, vol. I-8 (E. F. W. Gibb Memorial Series, N.S., IV: I-8), London I925-40.

2 Tales from the Masnavi, London 196r, p. 21. 
Sehnt doch nach des Zusammenweilens Glück

Der Heimatferne allzeit sich zurück.

Klagend durchzog ich drum die weite Welt, Und Schlechten bald, bald Guten beigestellt,

Galt jedem ich als Freund und als Gefährte,

Und keiner fragte, was mein Herz beschwerte,

Und doch - so fern ists meiner Klage nicht,

Den Sinnen nur fehlt der Erkenntnis Licht.

So sind auch Seel und Leib einander klar,

Doch welchem Aug stellt je ein Geist sich dar?

Kein Hauch, nein Feuer sich dem Rohr entwindet,

Verderben dem, den diese Glut nicht zündet!

Der Liebe Glut ists, die im Rohre saust.

Der Liebe Seufzen, das im Wein aufbraust.

Getrennter Liebenden Gefährtin sie,

Zerreisst die Schleier uns die Melodie.

(Translation G. Rosen ${ }^{1}$ )

\section{The Song of the Reed}

Hearken to this Reed forlorn,

Breathing, even since 'twas torn

From its rushy bed, a strain

Of impassioned love and pain.

"The secret of my song, though near,

None can see and none can hear.

Oh, for a friend to know the sign

And mingle all his soul with mine!

'Tis the flame of Love that fired me,

'Tis the wine of Love inspired me.

Wouldst thou learn how lovers bleed,

Hearken, hearken to the Reed!"

(Translation R. A. Nicholson ${ }^{2}$ )

${ }^{1}$ Mesnewi oder Doppelverse des Scheich Mewlana Dschelal-ad-Din Rumi, Leipzig I849; quoted from W. Gundert, A. Schimmel und W. Schubring (eds.), Lyrik des Ostens, München 1952, pp. 9I f.

${ }^{2}$ Rümī, poet and mystic (Ethical and religious classics of the East and West, I), London I950, p. 3I; for an exact prose translation by Nicholson, see his The Mathnawi of Falálu'ddin Rúmi, 2, p. 5 . 
The $r u b \bar{a} \tau \bar{\imath}$ or quatrain apparently has its origin in an old, but in many Iranian dialects still existing, form of popular poetry often called $d u$-baitĩ ('double-distichon'). ${ }^{1}$ It consists of four hemistichs generally rhyming $a a, b a,{ }^{2}$ and when adapted to literary New Persian the metre is normalised to a rich but well defined set of variations of the quantitative measure hazaj. ${ }^{3}$

Some of the earliest known quatrains in Persian literature are associated with the name of a famous Sufi shaykh of the eleventh century, Abū Sa'îd ibn Abi'l-Khair (d. 440/1049). In about II 80 his great-great-grandson, a certain Muhammad ibn Munavvar, wrote a biography of him with the im-

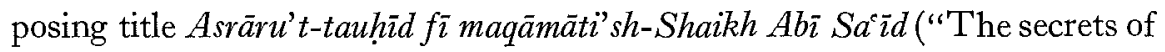
the unity of God concerning the stages of Shaykh Abü Sa'id"). This work is fortunately preserved ${ }^{4}$ and permits us something of an insight into the practical circumstances of the earliest Persian Sufism. Among other things we can read there the rules which Abü Sa'id laid down for the dervishes in the convent he conducted in Nishapur. ${ }^{5}$ This biography also quotes a number of $r u b \bar{a} \bar{\imath} y \bar{a} t$ alleging that they were of importance in the religious life and preachings of Abu Sa'id. Although it is expressively stated that he did not compose them himself but heard them from his elders, they came to serve as a kind of nucleus for quatrains of similar style and content, all of which were later collected and passed on in his name.

The Abū Sa'ĩd biography gives interesting information on the function of poetry in the life of the Sufis. Poems were sung, often by a special qavvāal ('singer'), at important stages in the preaching of the shaykh or otherwise

1 For a different view, see F. Meier, Die schöne Mahsatī; ein Beitrag zur Geschichte des persischen Vierzeilers, 1 , Wiesbaden 1963, pp. I2 $\mathrm{f}$.

${ }^{2}$ The less common variant $a a, a a$ is called $r u b \bar{a}^{-} \bar{\imath}-y i$ taränah, i.e. 'song-quatrain'.

${ }^{3}$ For the literary $r u b \bar{a} \bar{\imath}$ basically ——vv-/ - vv-/_-vv-/; cf. also Meier, Die schöne Mahsati, pp. 5 ff.; the original, preclassical metre was probably syllabic, and the modern popular type often uses a hendecasyllabic hemistich, often identified as hazaj-i musaddas: $\mathrm{v}-\longrightarrow-\mathrm{V}-\ldots-\mathrm{v}-\longrightarrow$; for a general survey, see J. Cejpek in J. Rypka (et al.), Iranische Literaturgeschichte, Leipzig 1959, p. 539; for connections with Middle Persian poetry, see H. S. Nyberg, ZDMG, 82, r928, p. 225; for the hendecasyllabic type in Tajik and Afghan folklore, see e.g. I. S. Braginskij, Iz istorii tadžikskoj narodnoj poėzii, Moscow I 956, pp. 205 f.; A. Khromov, "The problems of Yaghnobi folklore", Yãdnāme-ye fan Rypka, Prague r967, p. 259; Namunai fol'klori xalkhoi Afǵoniston, ruboiyot va surudho, Dushanbe 1966.

${ }^{4}$ And confirmed by a shorter biographical work by another great-great-grandson; cf. R. A. Nicholson, Studies in Islamic Mysticism, Cambridge I921, pp. I-76.

${ }^{5}$ Cf. Nicholson, Studies, p. 46. 
during the sessions of the dervishes. Such singing often caused raptures of extasy and at times also ecstatic dancing. According to other sources, e.g. the above-mentioned al-Hujviri, a frequent effect was that the dervishes tore or flung off their khirqah (the special patched dervish frock). It seems that $\mathrm{Abu \overline { } \mathrm { Sa }} \mathrm{i} \mathrm{i}$ also used quite profane quatrains, generally popular love-lyrics to which only the changed context conveyed a mystical signification. ${ }^{1}$

The $r u b \bar{a} \bar{\imath}$ was soon adopted by artistic poetry and as such developed traditions independent of the popular variant. As poetic form it was favoured by many of the great Sufi poets, such as Sanā'ì, 'Atțāar and Jalāl ud-dīn Rūmī. Already Anșāin of Herat, slightly younger than $\mathrm{Abu}$ Sa'ĩd, was a skilful composer of religious quatrains. One of the most well-known has been rendered in the following way by E. G. Browne. ${ }^{2}$

I need nor wine nor cup: I'm drunk with Thee;

Thy quarry I, from other snares set free:

In Ka ba and Pagoda Thee I seek:

Ka ${ }^{\mathrm{b}}$ ba, Pagoda, what are these to me?

Formally the $r u b \bar{a} \subset \bar{\imath}$ remained quite fixed, expressive through its great concentration, generally with an epigrammatic twist in the last hemistich in which the rhyme returns, "somewhat as in the Greek Alcaic, where the penultimate line seems to lift and suspend the Wave that falls over in the last", as Edward FitzGerald puts it. ${ }^{3}$

In order to elucidate the origins of the characteristic symbolism of Sufi poetry and to sketch the background of the main poetical form of Sufi lyrics, i.e. the ghazal, we have to turn our attention once more to the earliest stages

\footnotetext{
${ }^{1}$ Berthels, "Proisxoždenie sufizma", Izbr. trudy, [3], pp. $47 \mathrm{ff}$.

2 A Literary History of Persia, 2, p. 27o; cf. Berthels, "Proisxoždenie sufizma", Izbr. trudy, [3], p. 5 o.

${ }^{3}$ End of the Preface of the 4 th ed. of his Rubaiyat of Omar Khayyám; it should not be denied that FitzGerald in his excessively famous paraphrases of these $r u b \bar{a} \bar{\imath} y \bar{a} t$ has succeeded well in reproducing in English the characteristics of this form; further it should be noticed that 'Umar Khayyäm (d. $c .5$ I5/II22) definitely does not belong to the class of poets here treated, in spite of all attempts to make a good Sufi shaykh of him, as e.g. recently by Robert Graves and Omar Ali-Shah (The Rubaiyyat of Omar Khayaam: a new transl. with critical commentaries, London 1967; see also Life, 44, 1968:4, 4/3, pp. 24-27); however, there may be an interesting parallelism between the problems with 'Umar's "spurious quatrains" and the condensation process mentioned above in connection with the Abū Sa'id quatrains.
} 
of Sufism. Already the Arabic ascetics attached great importance to a practice called $d h i k r$ (prop. 'reminding oneself'), a combination of prayer and technique of concentration which consisted of a persistent repetition of the name of God or some of the central religious formulas, as e.g. lä iläha illā 'lläh, 'there is no god but God'. It was practiced individually or collectively, by tongue or thought, and aimed at a weakening or even dissolution of the self. ${ }^{1}$ When the ascetic movement developed into full-grown mysticism centred on a positive love of God, the practice of $d h i k r$ remained one of the most important, but as a method to attain what the Sufis call $h \bar{a} l$, i.e. the extasy, it was supplemented with samāe, 'audition', most probably originating in Koran recitations, but soon including music and singing of poetry and, finally, dancing. 2 That "concerts" of this kind were not exempt from certain risks was testified already by the quotation from al-Hujvirin given above, and $s a m \bar{a}^{c}$ always remained a controversial subject for the Sufi theorists who generally make a point of declaring that only the factual use, for good or for bad, determined if it could be considered allowable or not.

It seems as if the 8th century woman mystic Rābie a al-'Adawiya played a leading part in the inauguration of a specific Sufi poetry. ${ }^{3}$ It is well known how she was sold as a slave in tender years and, after many years, set free on account of her saintliness, but it is possible that she was also a professional singer. However this may be, in her religious poetry we find for the first time an extatic love of God expressed through the attributes of profane love lyrics. Along with such original compositions as those of Rābie a we have to consider the practice of the dervishes, already touched upon in the case of $\mathrm{Abu} \mathrm{Sa}^{\mathrm{i}} \overline{\mathrm{i}} \mathrm{d}$, to use worldly love and wine poems in their sessions for religious purposes. Of course, these poetical conventions accompanied the sam $\bar{a}^{\mathrm{a}}$ when it was brought to Iran, and, changing language to Persian, Sufi lyrics there grew out of the same kind of transposed erotic poetry (to which the wine symbolism already belonged). Probably the Persian form of mystic poetry from the outset was more popular in its ways of expression than the Arabic, which would explain why it always remained simpler and more directly

\footnotetext{
${ }^{1}$ See L. Gardet, "Dhikr", Encyclopaedia of Islam, new ed., 2, pp. 223-227.

${ }^{2}$ Cf. Berthels, "Proisxoždenie sufizma", Izbr. trudy, [3], pp. 43 f., "Osnovnye momenty", Izbr. trudy, [3], pp. $57 \mathrm{f}$.

${ }^{3}$ Cf. Berthels, "Proisxoždenie sufizma", Izbr. trudy, [3], pp. I7 f.; "Osnovnye

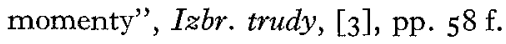


emotional and thus also obtained such an extraordinarily broad influence on Persian cultural life.

The ghazal must be considered the main form of Sufi lyrics in Persian, such as they are preserved from the eleventh century onwards. This form, consisting of five to fifteen verses loosely connected as to contents but rhyming on the same rhyme right through, was common at least as early as in the tenth century for profane Persian poetry and in Arabic some three hundred years earlier. Its origin has been much discussed, one theory suggesting the erotic prelude (nasi $\bar{b}$ ) of the old Arabic qașida and another setting forth some kind of lyric supposed to have been sung in pre-Islamic Persia. ${ }^{1}$ In Persia the great Sufi poets, as e.g. Sanā'ì and Jalāl ud-dīn Rūmī, brought this form to its perfection. In the 12 th and $I 3$ th centuries the originally emotional and intuitive symbolism was given a firm structure on the basis of Sufi philosophy, especially the metaphysical speculations of Ibn al-'Arabī (d. 638/ I240) and the doctrine of the Perfect Man (al-insān al-kāmil). ${ }^{2}$ But when these terms and metaphors from the sphere of profane love and winedrinking once and for all had been locked to a rigid terminological scheme, then the seed of future conventionalism and sterile repetition had been sown. It lasted, however, some three hundred years until such downward trends finally gained the upper hand, and in the meanwhile a great number of eminent poets successfully sang the perfection of the Beloved and expressed the inexpressible mystic experience.

Finally there appeared in the classical poetry as a whole a particular and fascinating phenomenon. The double legacy of court poetry and popular love lyrics on the one hand and a widely current mystic poetry on the other created an intricate poetical situation in which the ways of expression came to interact. The Sufi symbolism was lent back to the profane poetry out of which it had once developed, but simultaneously this same symbolism was re-coloured with sensuous associations also in mystic poetry. Through this interaction especially the lyric poetry acquired a fruitful ambivalence which

${ }^{1}$ See J. Rypka (et al.), Iranische Literaturgeschichte, pp. 96f. and refs. there; A. J. Arberry, Fifty poems of Häffz, Cambridge 1947 (repr. 1962), pp. $22 \mathrm{f}$.

${ }^{2}$ Cf. H. H. Schaeder, "Die islamische Lehre vom Vollkommenen Menschen, ihre Herkunft und ihre dichterische Gestaltung", $Z D M G, 79$, 1925, pp. 192-268, and esp. part 6: "Der Vollkommene Mensch als beherrschendes Stilmotiv der persischen Lyrik", pp. 245-26r. 
was often used as a conscious artifice of style, but perhaps even more often remained on an unconscious level of sensuous-religious experience in the mind of the poet (and reader/listener). Not seldom when reading classical Persian poetry, pronouncedly mystic or not, it seems relevant to ask who this Beloved actually is, who is described with all these concrete attributes. Thus e. g. the glowing mystic Fakhr ud-dīn 'Irāqĩ (d. 688/r289) does not for a moment conceal that the Beloved is a quite terrestrial shähid, i.e. a 'witness' of the perfection of God. ${ }^{1}$ While the great master of the ghazal, Shams ud-din Muhammad Haafiz (d. 792/139o), so dazzles his reader that he sees in the poems of that "Tongue of the Unseen" exactly what he wants to see, be he orthodox, mystic or sceptic.

${ }^{1}$ Cf. H. Ritter, Das Meer der Seele, pp. $482 \mathrm{ff}$. 